heavens in the neighbourhood of its projected track with considerable optical power may be necessary, and it will be particularly a case where the Astronomer-Royal's principle of mounting involved in his "orbit-sweeper" might be brought into useful requisition.

ENCKE'S COMET.-Mr. John Tebbutt, of Windsor, New South Wales, announces his re-observation of the comet of Encke, in the evening twilight on August 3, with the aid of the late Dr. von Asten's ephemeris, which had reached him on July 22 . On August 5 it was pretty bright in a $4 \frac{1}{2}$-inch refractor, notwithstanding the moonlight, and Mr. Tebbutt hoped to secure a good series of positions. This comet has not passed unobserved at any appearance since its periodicity was discovered by Encke nearly sixty years ago.

BRORSEN's COMET.-Prof. Schulze, of Döbeln, has published an ephemeris of Brorsen's comet of short period for the reappearance in 1879 , founded upon a new discussion of the observations at the last two returns, and the application of the perturbations of Venus, the Earth, Mars, Jupiter, and Saturn. The comet will arrive at perihelion on March 30, and at its least distance from the earth on May 9, about which time its north declination will exceed $65^{\circ}$, so that it will be very favourably situated for observation in these latitudes. Prof. Schulze thinks the comet may be detected at the southern observations before the end of February.

NEW MiNoR PlanETS.-Two new minor planets have been added to the list : the first detected by Prof. Peters, at Clinton, U.S., on September 18 , the second by Prof. Watson, at Ann Arbor, on September 22-thus raising the number of known members of the group to I9o.

\section{AUGUSTUS HEINRICH PETERMANN}

WE regret to record the sudden death, at Gotha, on September 26, of Dr. Augustus H. Petermann, one of the first cartographers of the present day. He was born at Bleicherode, in the neighbourhood of Nordhausen, Prussia, April 18, 1822. Although destined by his parents for the church, a pronounced taste for geographical study led to his entrance, at the age of seventeen, into the Geographische Kunstschule, founded shortly before at Potsdam, by Berghaus. Here, under the guidance of this famous geographer, he made rapid progress, and soon attracted the attention of leading savants. Among others Humboldt became interested in him, and entrusted him, when but nineteen years of age, with the preparation of the map accompanying his wellknown work on Central Asia. Four years later, in I845, he went to Edinburgh, in order to assist in the preparation of the English edition of the great Physical Atlas of Berghaus, issued by Johnston. Accompanying Petermann to Edinburgh was Henry Lange (now Dr. Lange, of the Berlin Statistical Bureau). These two, along with the late Keith Johnston, made an interesting tour through the Scottish Highlands, one result of which was a sketch or diagram of the Grampian range by Petermann, which he afterwards, we believe, published in London. In 1847 he settled in London, and was promptly elected into the Royal Geographical Society. His seven years' residence in London (1847-54) was one of continuous activity. Aside from the numerous maps which he executed, he contributed regularly to the Athenceum a résumé of the progress of geographical discovery, and issued, in union with Thomas Milner, an "Atlas of Physical Geography," and a fine folio atlas to illustrate Barth and Oberweg's travels in Africa. Two other maps which Petermann brought out during his stay in London still maintain their place on Stanford's list-a hydrographical and a population map of the British Islands. It was the publication of these maps, we believe, which enabled him to obtain the favourable notice of Baron Bunsen, who mate- rially assisted Petermann in his progress. His connection with English publishers has always been close, and the last edition of the "Encyclopredia Brittanica" contains a number of admirable geographical articles from his pen. In 1855 he returned to his native land to take the management of Justus Perthes' Geographical Institute in Gotba, where an unlimited field was offered to his restless activity. In the same year he commenced the publication. of the Mittheilungen, the successor of the Geographisches Fahrbuch, started by Berghat1s. Under his careful editorship this periodical has become almost indispensable to those desiring to keep au courant with the progress of geographical discovery. No small portion of its rich and varied contents, as well as of its finely-executed maps, were due directly to Petermann. As cartographer Petermann was unwearied, and a constant succession of admirable maps have been executed by hin during the past twenty-five years. Among these we might mention especially a great part of the magnificent collection forming Stieler's "Grosser Atlas," completed two years since; the map of the United States (1875), regarded by the government officials of that country as the most perfect extant; the maps accompanying the African travels of Barth and Rohilfs; and the lately-issued charts of the Arctic regions and the Turkish empire.

It is, however, chiefly by his criticism, his advice, and his enthusiastic, unwearied support of all attempts at geographical discovery, that Dr. Petermann has rendered his greatest services. Standing practically at the head of European geographers, the depositary of all that was being attempted or had been executed, esteemed and regarded by the authorities of the leading nations, he has enabled, by his personal efforts and wide-spread influence, many of our prominent explorers to find the necessary sinews of war, and successfully realise their plans of travel. Two great departments of geographical exploration have specially possessed his sympathies. The first was that of Arctic exploration, and dates from the interest excited during his residence in England, by the expeditions sent forth in search of Franklin. It was almost entirely due to his exertions that the German government equipped the successive expeditions of Werner (I865), Koldewey (1868), and Koldewey and Hegemann (I869), all of which aimed at the exploration of the east coast of Greenland-Petermann's favourite route for approaching the Pole. His advice was likewise of material assistance in the preparations for the late Austrian, English, Dutch, and Swedish expeditions, and few voyages to the icy regions have been undertaken of late years without consultation with Petermann on the general plan.

A still deeper interest was shown by him in the matter of African travel. The important expedition of Barth, Overweg, and Vogel, in 1849 , was instituted by the Prussian Government, chiefly on the recommendations of Bunsen and Petermann. Heuglin's and Munzinger's expedition in $186 \mathrm{r}$ was also due entirely to his instigation. Rohlfs' journey in Morocco, as well as Mauch's expedition in South Africa, would have been impossible without his assistance, and his name is closely associated with the important expeditions of Schweinfurth and Nachtigal.

The numerous contributions of Petermann to geographical literature are contained in the Mittheilungen, with the exception of those published in English. Of late years he has occupied the chair of geography at the Gotha Polytechnic.

As we have said, the Geographische Mitthcilungen has become indispensable to all who wish to keep pace with the progress of geography; and from its pages a fair idea may be obtained of the all-comprehensiveness of that department of knowledge. We are glad to learn, from a circular signed by Dr. Behm, the efficient colleague of Petermann, that this facile princeps of geographical 
journals is to be continued. We trust its comprehensiveness, thoroughly scientific character, and general high standing will be maintained, and that it will continue a permanent monument to the genius, hnowledge, and zeal of its founder.

\section{THE NORWEGIAN NORTH ATLANTIC EXPEDITION}

THE Vöringen left Hammerfest on July 29 on its last cruise. On the 3Ist, at noon, Bear Island was reached. Here the expedition was kept till August 3, the weather being too stormy to allow sea work to be done. In the night of August I-2 a party landed on the east side of the island, where the sea was sufficiently smouth to allow a boat to land: but foggy weather interfered with any observations of importance being made. Some birds were shot and some fossils collected. In the morning hours extensive fishing operations were carried on from the deck of the ship, now anchored in some 12 fathoms. From 4 to 7 A.M. 200 large cods were hauled. From a point about midway between Bear Island and Spitzbergen we worked first up a cross section towards west-north-west, till we found 1, I49 fathoms' depth on the afternoon of the 4th. From this point the course was shaped for South Cape, Spitzbergen. At noon on the 5 th we made the cape, sailed round the island lying off the cape, and entered the Stor-Fjord. Here the sun was shining and the water smooth, so Capt. Wille swung the ship for deviation. The next morning we dredged on the bank lying south-east of South Cape; here the temperature was - $I^{\prime \prime} \cdot 2$ C. at the bottom, in 140 fathoms, and zero in I 20 fathoms. In the upper layers the temperature was very irregularly distributed, both increasing and decreasing with depth. We went again round the islands and to the west side of South Cape, taking here a departure for a larger cross section along the parallel of the cape towards Greenland. Having crossed the Spitzbergen bank, we sounded $523,743,1,017,1,429,1,487$, and I, 686 fathoms, when we at last, on August 8 , were stopped by the ice in $76^{\circ} 26^{\prime} \mathrm{N}$. lat. and $0^{\circ} 29^{\prime} \mathrm{W}$. long. Off the Spitzbergen bank we found $0^{\circ} \mathrm{C}$. in a depth of 470 fathoms. The polar current was reached in long. $5^{\circ} \mathrm{E}$. Station No. 360, where we met the ice, gave the following serial temperatures characteristic of the polar current:-Surface, $3^{\circ} \cdot 2$ C., 40 fathoms, $-1^{\circ} 3$; 70 fathoms, $-0^{\circ} 3$; 200 fathoms, $-0^{0.7} ; 300$ fathoms, $-1^{\circ} 0 ; 1,686$ fathoms at bottom, $-\mathrm{I}^{\circ} \cdot 3$. On this station we lost a trawl and 2,163 fathoms of dredge rope. The sea-bottom between Spitzbergen and Greenland was very rough; the trawl or dredge seldom came up without damage or having stones inclosed, some of which were rather heavy. We sailed, on August 9, northwards along the ice, and reached our next cross section on the roth, lat. $77^{\circ} 50^{\prime}$, long. $0^{\prime} 9^{\prime} \mathrm{W}$. The soundings were, from west to east, I, 640, 1,686, I,333, I, 343, 948, iro fathoms. The polar current closed in about $4^{\circ} \mathrm{E}$. long. Farther east, $\mathrm{o}^{\circ} \mathrm{C}$. was found in 300 to almost 500 fathoms. On Station No. 354 , lat. $78^{\circ} \mathbf{1}^{\prime}$, long. $6^{\circ} 54^{\prime} \mathrm{E}$., we had the great satisfaction of verifying the Swedish sounding made in 1868 at the same place by von Otter in the Sofia. The Swedes found 1,350 fathoms, we found 1,343 . This agreement gives me great confidence in von Otter's soundings, which were made with less perfect means than ours. The Swedish deep-sea soundings in the Sofia extend far westwards and northwards from Spitzbergen, and are therefore of the greatest importance. From our last cross-section we took a longitudinal section parallel to the coast of Spitzbergen. The depths reached were $42 \mathrm{I}$ fathoms (temperature $0^{\circ} \circ$ ), 905 fathoms, and 459 fathoms in lat. $79^{\circ} 59^{\prime}$, long. $5^{\circ} 40^{\prime} \mathrm{E}$. There was $0^{\circ}$ in 390 fathoms depth. There was ice floating in the surface temperature at $5^{\circ}, 2$. This brought our section to a close.

It appears that here on the 8oth parallel, the warm Atlantic current is still running northwards, backed up on the west coast of Spitzbergen. The polar ice, driven by northerly winds, is swimming on its back, and melted gradually off just like the end of the glaciers in the summer heat of the valleys. It was apparent that the current was rather strong towards the north, the ship's place being always, by observations and bearings, found more northerly than by dead reckoning. On the open sea it was found very difficult, not to say impossible, to determine the ship's place with the ordinary accuracy. The horizon was generally-as we observed when off the shore-lifted by a sort of mirage.

On August 15 we dropped our anchor at the Norway Islands, Nortb Spitzbergen, where we took in some ballast. In the sound, where we were lying, the beach was formed of mere loose stones, granite, apparently burst asunder by frost. Flakes and small bergs of ice sailed through the sound with the tide and were often touching the shore, but I could not observe there any sign of the ice cutting any line or mark along the beach. From the Norway Islands we went out off Hackluyt Head, where we took a sounding, passed the Smeerenberg and the South Gat, and anchored in Magdalena Bay. The Admiralty chart of the last-named places, surveyed in 1818 by Franklin and Beechy, proved very accurate. In Magdalena Bay we found a bottom temperature of $-1^{\circ} .7$ to $-2^{\circ} \mathrm{O}$, in exact agreement with the results formed by $M$. Charles Martins in 1839 in the La Recherche expedition. Our last visit was in the Advent Bay ice-fjord, where Capt. Wille constructed a chart of the bay, assisted by Capt. Grieg and myself, who measured the base line, some trigonometrical angles, and took altitudes for latitude and longitude. Foggy weather prevented our visit to Bell Sound. On August 23 we left Spitzbergen, and on the 26th we anchored at Tromsö. On September 4 the Vöringen returned to Bergen and the expedition was closed. The three summers have yielded in all 375 sounding-stations, I 3 temperature series, 44 dredgings, and 42 trawlings.

H. MOHN

\section{THE ANCIENT CAPITAL OF ITHACA}

$\mathrm{TN}$ a recent letter to the Times Dr. Schliemann describes his search for the ancient capital of the island of Ithaca. He began his researches in the valley called Polis, which is in the northern part of the island, and has generally been considered as the site of the Homeric capital of Ithaca-first, on account of its name, which is the Greek word for city; second, on account of its splendid harbour, at a distance of only two miles from a small island now called Mathitarió, which, being the only one in the strait between Ithaca and Cephalonia, has naturally always been identified with the Homeric island of Asteris, behind which the suitors of Penelope were in wait for Telemachus on his return from Pylos and Sparta ("Odyssey," iv., 844-847). As a fourth reason for the identity of Polis with the site of Ithaca's capital, he mentions an acropolis which one thinks to perceive on the very steep rock, at a height of about 400 feet, on the north side of the port. Dr. Schliemann found it to consist of a very irregular calcareous rock, which had evidently never been touched by the hands of man, and can most certainly never have served as a work of defence. There can be no doubt that the name of this valley is derived not, as has been hitherto thought, from a real city, but merely from an imaginary fortress.

Besides, this valley is the most fertile spot in Ithaca, and it can therefore never have been used for the site of a city; in fact, it never yet occurred in Greece that a city should have been built on fertile land, and least of all can such have been the case on the rocky island of Ithaca, where arable land is so exceedingly rare and precious. 